\title{
Effectiveness of Pre-operative Tranexamic Acid Administration Against the Amount of Bleeding During and After Open Reduction Internal Fixation (ORIF) in Closed Femur Fractures

\author{
Hengky Irianto ${ }^{1}$, Primadika Rubiansyah ${ }^{1 *}$
}

${ }^{1}$ Department of Surgery, Faculty of Medicine, Universitas Sriwijaya

*Corresponding Author Email: primadikarubiansyah@gmail.com

\begin{abstract}
Introduction. In femoral fractures case, bleeding often occurs and is accompanied by injury to other organs, so the possibility of impaired circulation (shock hemorrhagic) will be greater, especially at productive age. This study was aimed to evaluate the benefits of giving pre-operative tranexamic acid to sufferers of femur fractures accompanied by circulatory disorders and without circulation disorders in reducing peri-operative and postoperative bleeding ORIF.

Method. This study was a clinical experimental test with a cohort design at the Central Surgical Installation of Dr. Mohammad Hoessin Hospital Palembang. Samples were taken from patients who underwent ORIF Femur surgery, with a type of Hansen Winquist fracture type 0-2, which was pierced with tranexamic acid $10 \mathrm{mg} / \mathrm{Kg} \mathrm{BW}$.

Result. Intraoperative hemorrhage in ORIF in both treatment groups where patients with a history of preoperative shock had more amount of bleeding than the group who had no history of preoperative shock. Whereas from the amount of post-operative drainage, there were no significant differences in the two treatment groups.
\end{abstract}




\section{SSS SRIWIJAYA JOURNABOFSURGERУ}

Conclusion. The group of patients with a history of hemodynamic disorders (shock) given intravenous tranexamic acid, is useful in reducing intraoperative bleeding, but not significant to reduce postoperative bleeding in both treatment groups

Keywords. tranexamic acid, open reduction internal fixation, closed femur fracture

\section{Introduction}

Of all musculoskeletal trauma, femur fractures are a type of trauma that is often found in the productive age group, and most of the treatments require surgery. ${ }^{1}$ Types of surgery on femur fractures that are often open reduction and deep reduction (open reduction and internal fixation $=$ ORIF). The tissue around the thighs is classified as thick and rich in a significant blood supply, moreover the location of the surgery makes it impossible to place a tourniquet.

Based on data in the Central Surgery Unit of Dr Moh Hoesin General Hospital in 2014 ORIF had been performed on femur as many as 48 cases, without fractures elsewhere. ${ }^{3,4}$ Bleeding due to ORIF surgery in the femur is classified as preventable bleeding, so it needs maximum effort. to avoid it, and factors that cause a lot of intraoperative bleeding include: (1) ineffective local hemostasis, (2) complications from blood transfusion, (3) duration of surgery, and (4) fibrinolysis. ${ }^{5,6}$ Large perioperative bleeding surgery orthopedics such as total hip or total knee, is still a problem that increases post-surgical complications and even death. ${ }^{7,8}$ Perioperative blood loss requires large transfusions with post-surgical complications such as haemostasis, coagulopathy, acute lung injury, hemolytic reactions, allergic reactions, bacterial sepsis, embolism, thrombophlebitis, overtransfusion. $5,6,9$

Various methods are used to reduce perioperative bleeding including the use of tranexamic acid which has been tested even though the number of samples is not large enough. Tranexamic acid works to prevent the activation of plasminogen into plasmin which plays a role in fibrin degradation thereby preventing fibrinolysis and clotting from progressing. Various studies have shown complications for the use of tranexamic acid, such as thromboembolic. ${ }^{8,10-15}$

Fluid resuscitation and transfusion of patients with circulatory disorders in patients with femoral fractures have been shown to interfere with hemostasis, especially blood clots. ${ }^{16-21}$ This 


\section{SSS SRIWIJAYA JOURNABOPSURGERY}

situation is thought to affect the use of tranexamic acid on reducing transfusion compared to patients without circulatory disorders. ${ }^{18,19}$

However, no research has been conducted to examine the effectiveness of tranexamic acid in reducing bleeding in ORIF surgery for long bones with fractures of the femur with or without circulatory disorders (hemorrhagic shock). Where is estimated bleeding in femoral bone fractures $\pm 2000 \mathrm{cc}$, and accompanying injury factors in other organs that are accompanied sometimes accompanied by hemorrhagic shock marked by changes in vital signs.

\section{Methods}

This study is a cohort study that observed the effectiveness of giving tranexamic acid to the amount of bleeding during and after ORIF surgery with implant plates and screws or K-Nails in patients with femoral bone fractures with impaired circulation (hemorrhagic shock) and those with femoral bone fractures. not experience post-traumatic circulation disorders. Inclusion criteria were patients with closed femur fractures Hansen Winquist criteria 0-2, aged 18-80 years, platelets $\geq 150,000$ / ul, PT 11.5-13.4 seconds, aPTT 27-38 seconds. Exclusion criteria were patients with contraindications to tranexamic acid, patients with diseases that could cause blood clotting disorders, such as hemophilia and thrombocytopenia, patients assessed through pre-operative examinations including laboratories, patients with neglected femur fractures, patients with revised femur fractures, patients with revised cases Pathological fracture.

The first is an F-Test analysis of population characteristics and fracture type, to assess the homogeneity of the sample. Then to assess the differences between quantitative data, an independent sample t-test was used. Differences in proportions and qualitative data are tested by multiple analysis of variance. Data are expressed as mean \pm standard deviation, with values $<0.05$ considered significant. Analyzes were performed using PASW statistics version 18 (SPSS Inc) software.

\section{Results}

Analysis of 48 subjects of this study of the amount of intraoperative bleeding obtained the lowest amount of drain of $350 \mathrm{cc}$ and the highest $1000 \mathrm{cc}$. Based on the distribution of the amount of drainage that appears to be normally distributed, the Saphiro-Wilk test ( $p>0.05)$ is seen in table 


\section{SSS SRIWIJAYAJOURNAB OFEURGERY}

1. The variables observed in this study were the amount of intraoperative bleeding measured after surgery until the wound was closed. The results of the measurement of the number of intraoperative deliveries in the two treatment groups are presented in the following table.

Table 1. The average amount of intraoperative bleeding for both groups of sufferers

\begin{tabular}{|c|c|c|c|c|}
\hline \multirow{2}{*}{$\begin{array}{l}\text { Amount } \\
\text { intraoperative } \\
\text { bleeding }\end{array}$} & \multirow[b]{2}{*}{$\mathrm{N}$} & \multicolumn{2}{|c|}{ Mean \pm SD } & \multirow[b]{2}{*}{$p$ value } \\
\hline & & $\begin{array}{l}\text { Preoperation Shock } \\
(\mathrm{ml})\end{array}$ & $\begin{array}{l}\text { Without Shock } \\
\text { (ml) }\end{array}$ & \\
\hline $\begin{array}{l}\text { Intraoperative } \\
\text { bleeding }\end{array}$ & 48 & $731,25 \pm 105,10$ & $637,50 \pm 129,59$ & 0,008 \\
\hline
\end{tabular}

*)unpaired t test

Based on the calculation of the average value of the amount of intraoperative bleeding from a group of subjects given tranexamic acid who experienced preoperative shock and without preoperative shock seen differences in the amount of blood obtained during surgery. After a statistical test (independent t test) was found that there was a statistically significant difference in the amount of intraoperative bleeding in patients who experienced preoperative shock and without preoperative shock after receiving intravenous tranexamic acid injection where $\mathrm{p}=0.008(\mathrm{p}$ $<0.05)$.

Analysis of 48 subjects of this study of the amount of postoperative hemorrhage obtained the lowest amount of $75 \mathrm{cc}$ and $325 \mathrm{cc}$. Based on the distribution of the amount of drainage appears to be normally distributed, Saphiro-Wilk ( $p>0.05$ ). The variable observed in this study was the amount of drainage measured after surgery until production ceased to exist with an interval of one day of measurement. The results of the measurement of the amount of drain in the two treatment groups are presented in table 2. 


\section{STS SRIWIJAYA JOURNABOFEURGERY}

Table 2. Average number of postoperative bleeding for both groups of sufferers

\begin{tabular}{lcccc}
\hline & & \multicolumn{2}{c}{ Mean \pm SD } & \\
\cline { 3 - 4 } Total drain (day) & $\mathrm{n}$ & $\begin{array}{c}\text { Preoperative Shock } \\
(\mathrm{ml})\end{array}$ & $\begin{array}{c}\text { Without shock } \\
(\mathrm{ml})\end{array}$ & $p$ value \\
& & $88,54 \pm 16,17$ & $102,08 \pm 52,25$ & 0,231 \\
\hline $1^{\text {st }}$ day & 48 & $25,83 \pm 8,80$ & $24,58 \pm 13,18$ & 0,701 \\
$2^{\text {nd }}$ day & 48 & $10,83 \pm 5,25$ & $9,38 \pm 3,99$ & 0,284 \\
$3^{\text {rd }}$ day & 48 & $124,38 \pm 17,96$ & $136,04 \pm 54,13$ & 0,322 \\
Total Drain & 48 & & & \\
\hline
\end{tabular}

*)unpaired t test

Based on the calculation of the average value of the amount of postoperative bleeding from a given group of subjects who experienced preoperative shock and without preoperative shock seen differences in the amount of blood obtained in the drain. After a statistical test (independent t test) was found that there was no statistically significant difference in the number of postoperative hemorrhages in patients with preoperative shock and without preoperative shock after receiving intravenous tranexamic acid injection either on day 1, day 2, day 3 and total drain ( $\mathrm{p}>0.05)$.

\section{Discussion}

From the results of this study, the amount of bleeding varied with intraoperative bleeding in the two treatment groups, the lowest number of intraoperative bleeding was $350 \mathrm{cc}$ and the highest was $1000 \mathrm{cc}$. In the same period of observation, the drainage hose installed contained a number that varied with the amount of drain in the two treatment groups, with the lowest total drain being $75 \mathrm{cc}$ and the highest $325 \mathrm{cc}$. Intraoperative hemorrhage in ORIF in both treatment groups where patients with a history of preoperative shock had more amount of bleeding than there was no history of preoperative shock. In statistical calculation of the significant differences in preoperative administration of tranexamic acid in reducing the amount of intraoperative bleeding with a value of $\mathrm{P}=0.008(\mathrm{P}<0.05)$. Postoperative ORIF bleeding in the two treatment groups where the amount of bleeding in the drain was almost the same in the two treatment groups, after being observed while the drain was still attached until the drain was removed. The average total postoperative bleeding was $124.38 \pm 17.96 \mathrm{cc}$ in patients with a history of shock, and $136.04 \pm 54.13 \mathrm{cc}$ in 


\section{SSS SRIWIJAYA JOURNAL OFSURGERY}

patients without a history of previous shock. Statistical tests conducted on the two groups found no significant relationship in the two treatment groups. Both of the above contradict with previous studies where, the use of tranexamic acid with a dose of $10 \mathrm{mg} / \mathrm{kgBW}$ given before surgery by bolus significantly reduced the amount of postoperative bleeding in patients undergoing knee joint atroplasty surgery, but in that study it was stated that there were no significant differences in the amount of intraoperative bleeding between patients given tranexamic acid with the placebo group. ${ }^{25}$ Other studies have shown that administering tranexamic acid in a single bolus can reduce the amount of perioperative bleeding in hip fracture surgery and scoliosis correction. ${ }^{25}$ It is also said that if this drug is given in the middle or end of surgery, there are no serious side effects from this administration of tranexamic acid. ${ }^{22,25}$

\section{Conclusion}

Intravenous tranexamic acid in a group of patients with a history of hemodynamic disorders (shock) is useful in reducing intraoperative bleeding, but is not significant to reduce postoperative bleeding in both treatment groups.

\section{References}

1. Nieves JW, Bielezikian JP, Lane JM, Einhorn TA, Wang Y, Steinbuch TM, et al. Fragility fractures of the hip and femur: incidence and patient characteristics. Osteoporosis Int. [update 2009]. Tersedia dari: http://www.ncbi.nlm.nih.gov/pubmed/19844169

2. Solomon L, Warwick DJ, Nayagam S, editor. Apley's system of orthopaedics and fractures, $9^{\text {th }}$ ed. London: Arnold;2001

3. Nork SE. Fractures of the shaft of the femur. Dalam: Bulcholz RW, Heckman JD, CVourtBrown C, editor. Rockwood and green's fracture in adults. Philadelphia: Lippincott; 2006. P. $1845-60$

4. Anonim. Jadwal operasi bedah sentral 2016. Instalasi Bedah Sentral RSMH. 2016

5. Keating M. Current options and approaches for blood management in orthopaedic surgery. J Bone Joint Surg. Am. May 1998;80:750-62 


\section{SISS SRIWIJAYA JOURNABOF SURGERУ}

6. Schwartz D, Kaplan KL, Schwartz SI. Hemostasis, surgical bleeding, and transfusion. Dalam: Brucinardi FC, Andersen DK, Billiar TR, Dunn DL, Hunter JG, Pollock RE, editor. Schwartz's principles of surgery. New York: McGraw-Hill; 2005.p.80

7. Rajiv Gandhi, Heather MK Evans, Safiyyah R Mahomed, and Nizar N Mahomed. Tranexamic acid and the reduction of blood loss in total knee and hip arthroplasty: a metaanalysis. BMC Research Notes. 2013, 6:184. Tersedia dari : http://www.biomedcentral.com/1756-0500/6/184

8. Keerati Charoencholvanich, Pichet Siriwattanasakul. Tranexamic acid reduces blood loss and blood transfusion after TKA. Clin Orthop Relat Res (2011) 469:2874-2880.

9. LieuranceR, Benjamin JB, Rappaport WD. Blood loss and transfusion in patient with isolated femur fractures. J Orthop Trauma. 1992;6

10. Teller DC. Coagulation cascade. Structure 5(1):125-138. 1997. Tersedia dari : http://www.bmsc.washington.edu/people.teller

11. Madden R. Perioperative assasment and care. Dalam: McCredie J, Burns G, Donner C, editor. Basic surgery. Toronto: Macmilan. 1990.

12. Steward DJ. Assasment of blood loss. Dalam: Manual of pediatric anesthesia edisi ke-3. New York: Churchill livingstone. 1990

13. Arasch Wafaisade, et al. Prehospital administration of tranexamic acid in trauma patients. Critical Care (2016) 20:143

14. Jennings, et al. Application of tranexamic acid in trauma and orthopedic surgery. Orthop Clin N Am 47 (2016)137-143

15. Jeff Simmons, et al. Tranexamic acid: from trauma to routine perioperative use. Curr opin anaesthesiol. 2015 April; 28 (2):191-200

16. Mark J. Midwinter, Tom Woolley. Resuscitation and coagulation in the severely injured trauma patient. Phil. Trans. R. Soc. B (2011) 366, 192-203.

17. Mitchell Jay Cohen. Towards hemostatic resuscitation; the changing understanding of acute traumatic biology, massive bleeding, and damage-control resuscitation. Surg. Clin. N. Am (2012) 877-891

18. Karthikeyan E. Ponnusamy, Thomas J. Kim, et al. Perioperative blood transfusions in orthopaedic surgery. J. Bone Joint Surg Am. 2014;96:1836-44. 


\section{STS SRIWIJAYA JOURNABOFEURGERY}

19. Sylvain Ausset, Elon Glassberg, Roy Nadler. Tranexamic acid as part of remote damagecontrol resuscitation in the prehospital setting: a critical appraisal of the medical literature and available alternatives. J Trauma Acute Care Surg Volume 78, Number 6, Supplement 1. 2015

20. Bhavani S. Vijay, Vikram Bedi, Subhro Mitra, Bikramjit Das. Role of tranexamic acid in reducing postoperative blood loss and transfusion requirement in undergoing hip and femoral sugeries. Saudi Journal of Anaesthesia Vol. 7, 2013.

21. Veena Chatrat, et al. Fluid management in patients with trauma: restrictive versus liberal approach. J Anaesthesiol Clin Pharmacol. 2015 31(3):308-316

22. Henley MB, Fractures of the femoral shaft and subtrchanteric region. Dalam:Brinker MR, editor. Review of orthopaedic trauma. Philadelphia; Saunders; 2001

23. Hoffbrandt AV, Pettit JE, Essensialhaematology. London: Blackwell. 1996

24. Griffin JD, Ellman L. Epsilon-aminocaproic acid. SeminThrombHemost. 1978 Summer; 5(1):27-40

25. Benon G, Fredin H, Fibrynolytic inhibition with tranexamic acid reduces blood loss and blood transfusion after knee arthroplasty. J Bone Joint Surg [Br]1996:78-B434-40 